INTERNATIONAL JOURNAL OF MULTIDiscipLINARY RESEARCH AND ANALysis

ISSN(print): 2643-9840, ISSN(online): 2643-9875

Volume 04 Issue 06 June 2021

DOI: 10.47191/ijmra/v4-i6-17, Impact Factor: 6.072

Page No.- 788-796

\title{
Comparative Study of Soil Index Properties of Gudu Sokoto State and Oworoshoki Area Lagos State, Nigeria
}

\author{
Peni I.T. ${ }^{1}$, Peni M.U. ${ }^{2}$ \\ ${ }^{1}$ Sokoto Energy Research Centre, Usmanu Danfodiyo University, Sokoto, Sokoto State, Nigeria. \\ ${ }^{2}$ Umaru Waziri Federal Polytechnic Birnin Kebbi, Kebbi State, Nigeria.
}

\begin{abstract}
The comparative study of the soils sample collected from Gudu and Oworoshoki area, Sokoto state and Lagos State was carried out to compare the index properties of soil at shallow soil deposit. The Global Positioning System (GPS) was used to locate the coordinates of the site. Shallow soil samples (disturbed and undisturbed) at different depths ( $1 \mathrm{~m}, 2 \mathrm{~m}$ and $3 \mathrm{~m})$ were collected from both study areas (Gudu and Oworoshoki). The disturbed samples were collected using hand trowel, digger, hoe and polythene bags while the undisturbed samples were collected using short pipes (samplers) by stroking each pipe into the ground completely with a hammer at each depth. Disturbed and undisturbed soils collected at different shallow depths (1m, $2 \mathrm{~m}$ and $3 \mathrm{~m}$ ) were taken to the laboratory for natural moisture content, specific gravity, sieve analysis, Atterberg limits and unit weight test. Empirical equations were used for analyzing the soil samples and AASTHO System of classification was used for classifying the soil samples. The results of the test on Gudu soil samples has shown that the soil sample collected at depth $1.0 \mathrm{~m}$ and $2.0 \mathrm{~m}$ are nonplastic materials and were classified according to AASHTO standard as A-3 and sample at depth $3.0 \mathrm{~m}$ as A-4 which is silty soil while Oworoshoki soil samples has shown that Soils from depth $1.0 \mathrm{~m}, 2.0 \mathrm{~m}$ and $3.0 \mathrm{~m}$ are nonplastic (NP) because the Plastic Index $(\mathrm{PI}=0)$ is zero and the soil samples are classified as A -3 according to AASHTO standard.
\end{abstract}

KEYWORDS: Soil sample, natural moisture content, specific gravity, sieve analysis, Atterberg limits

\section{INTRODUCTION}

Index properties of soil are these properties of soil that indicate the type and condition of the soil and provide a relationship to structural properties. Generally, index properties of soils are determined by laboratory testing on soil samples obtained from the site (Yoon et al., 2015). The relationship between all engineering infrastructure and their foundation soil are too important to be ignored. A considerable increase in soil utility for engineering works is expected as the country aspires toward improving infrastructural development. Incessant occurrence of road pavement failure and building collapse has made it imperative for proper understanding of the geotechnical properties of soils. Lack of geotechnical information and use of substandard materials has result the collapse of some buildings in Lagos, Oyo, Anambara, and Plateau State etc of Nigeria between 2018 and 2019. Expansive soil cause significant damage to structure and roadways by cyclic shrink-swell within the active zone of soil (Christodoulias, 2015).Expansive soils cause billions of dollars of damage to homes and property each year (Christodoulias, 2015). The significance of swelling soils in relation to geotechnical problems is now widely recognized. Geotechnical problems arising from expansive unsaturated soils are well demonstrated by many case histories all over the world, especially in geographical zones having arid, semi-arid and tropical climatologically conditions (Christodoulias,2015).The existence of specific expansive minerals in the clay soil related to the climatologically conditions, seasonable variation of rainfall precipitation (wet and dry periods) and fluctuation of water table in Mediterranean countries, has resulted to induce unexpected shrinkage and swelling movements with all the unfavorable consequences. It was observed that light industrial structures and small buildings suffer from heaving, road pavements to develop shrinkage cracks, canal lining and low embankments resting on swelling soil or embankments constructed with swelling soil, suffer distortion and cracking. If the propensity of a soil to shrink and swell is known before construction, shrinkage limit results can give information to design engineers, because if it is known the ability of soil to shrink or swell before construction, damage can be avoided. Geotechnical properties of soils influence the stability of civil engineering structures. The civil engineering structures like building, bridge, highway, tunnel, dam, tower, etc. are founded below or on the surface of the earth (Surendra, 2017). For their stability, suitable foundation soil is required. To check the suitability of soil to be 


\section{Comparative Study of Soil Index Properties of Gudu Sokoto State and Oworoshoki Area Lagos State, Nigeria}

used as foundation or as construction materials, its properties are required to be assessed (Laskar and Pal, 2012).Clay is predominant in most of the sub grade soils of Nigeria. Due to the relative abundance of these soil and ease of acquisition they have wide application in engineering construction works (Oyediran, 2011). Identification and classification can only be achieved through atterberge limit test (determination of liquid limit, plastic limit and linear shrinkage), specific gravity of soil particles, particle size distribution etc. For engineering purpose, soil is defined as any loose sedimentary deposit such as gravel, sand, silt, clay or mixture of these materials (smith, 1994). It is made up of various size of particles parked together with spaces between the particles known as voids. The voids are generally the mixture of air and water. A whole of laboratory test can be performed on soils to measure a wide variety of soil properties. Some soil properties are intrinsic to the composition of the soil matrix and are not affected by sample disturbance, while other properties depend on the structure of the soil as well as its composition, and are tested on relatively disturbed samples (Rorome and Ekeocha, 2015).Some soil test measure direct properties of the soil, while others measures index properties which provide useful information about the soil without direct measuring of the property desired (Rorome and Ekeocha, 2015). The previous work done in this area was also carried out by Akpokodje (1989; 2001) where he investigated the soil properties and pavement performance in the Niger Delta; the incidence of pavement failure of various roads in the Niger Delta, and correlated this with various factors such as rainfall, grain size distribution.(Rorome and Ekeocha, 2015) have conducted a study on geotechnical index properties of soil from various locations in Warri, Delta State. From his laboratory test results; Moisture Content (MC) ranges from 8.1- 26.9\%, Liquid Limit (LL) ranges from 22.0 - 38\%, Plasticity Limit (PL) ranges from 19.5 - 22.4\% and Plastic Index (PI) ranges from 2.1-17.9\%. He observed that the sample collected from the locations contain high percentage of fine soil (silt clay and fine sand) without gravel sized particles which was classified based on Unified Soil Classification Schemes (USC) as poorly graded, well drained, intermediate plasticity and medium swelling potential soil since it does not contain particles of all sizes. (Peni and Mustapha, 2019) have carried out a study on determination of properties of soil in Gudu Town, Sokoto, Nigeria. The result of the study has shown that the soil sample collected at depth $1.0 \mathrm{~m}$ and $2.0 \mathrm{~m}$ are non plastic materials and were classified according to AASHTO standard as A-3 while sample at depth $3.0 \mathrm{~m}$ as A-4 which is silty soil. (Peni and Mustapha, 2021) have conducted research on characterization and classification of geotechnical index properties of shallow soil deposits at oworoshoki area, where the result of the test has shown that Oworoshoki has natural moisture content as $23.5 \%, 24.5 \%$ and $25.3 \%$, liquid limits (LL) $28.68 \%, 26.64 \%$ and $29.10 \%$, Oworoshoki is non-plastic for the three depths i.e. plastic limit (PL) is 0, particle size distribution percentage passing through BS \#200 (0.075mm) are $95.97 \%$, 97.97\%, 98.10\% and this shows that the soil sample contain much silt, the samples are non-plastic for all depths (1m, $2 \mathrm{~m}$ and $3 \mathrm{~m})$, specific gravity as $2.61,2.55$ and 2.60 , unit weight as $17.5 \mathrm{KN} / \mathrm{m}^{3}, 18.1 \mathrm{KN} / \mathrm{m}^{3}$ and $18.9 \mathrm{KN} / \mathrm{m}^{3}$ and hydrometer percentage passing through BS \#200 $(0.075 \mathrm{~mm})$ as $95.97 \%$ at $1.0 \mathrm{~m}$ depth, $97.97 \%$ at $2.0 \mathrm{~m}$ depth and $98.10 \%$ at $3.0 \mathrm{~m}$ depth. Hydrometer test was conducted because $95.97 \%$ passes sieve $0.075 \mathrm{~mm}$. It was observed that the soil contain high amount of silt. Soils from depth $1.0 \mathrm{~m}$, $2.0 \mathrm{~m}$ and $3.0 \mathrm{~m}$ are non-plastic (NP) because the Plastic Index (PI=0) is zero and the soil samples are classified as $\mathrm{A}-3$ according to American Association of State Highway and Transportation Officials (AASHTO) System. (Oke and Amadi,2008; Nwankwoala and Warmate,2014) have highlighted that, assessment of geotechnical properties of subsoil at project site is necessary for generating relevant input data for design and construction of foundations for the proposed structures. Researchers (Oghenero et al., 2014) have stated that proper design and construction of civil engineering structures prevent an adverse environmental impact or structural failure or post construction problems. Information about the surface and sub-surface features is essential for the design of structures and for planning construction techniques. For complex projects involving heavy structures, such as bridges, dams, multi-storey buildings, it is essential to have detail exploration. The purpose of detailed explorations is to determine the engineering properties of the soils for different strata (Arora, 2008). Lack of understanding the properties of the soil can lead to the construction errors. The suitability of soil for a particular use should be determined based on its engineering characteristics and not on visual inspection or apparent similarity to other soils. The loading capability of soil depends upon the type of soil. Generally, fine grained soils have a relative smaller capacity in bearing of load than the coarser grained soils (Jain et al., 2015).Plasticity index and liquid limit are the important factors that help an engineer to understand the consistency or plasticity of clay (Surendra, 2017). This study is only concern with the variability of index properties of soil sample collected from Gudu and Oworoshoki.

\section{MATERIALS AND METHODS}

\section{Study Areas}

Sokoto is located in the extreme northwest of Nigeria. It shares boundaries with Niger Republic to the north, Zamfara State to the east and Kebbi State to the south. It occupies an area of 28,232.37sq.km and falls on latitude $13^{\circ} 3^{\prime} 25.18^{\prime \prime} \mathrm{N}$ and longitude $5^{0} 14^{\prime} 44.6022^{\prime \prime}$. The study area (Gudu Town) is located $15 \mathrm{~km}$ away from Sokoto town, and is as shown with an arrow indicating 


\section{Comparative Study of Soil Index Properties of Gudu Sokoto State and Oworoshoki Area Lagos State, Nigeria}

in Plate 1 bellow. Sokoto is located in the extreme northwest of Nigeria. It shares boundaries with Niger Republic to the north, Zamfara State to the east and Kebbi State to the south. It occupies an area of $28,232.37 \mathrm{sq} . \mathrm{km}$ and falls on latitude $13^{\circ} 3^{\prime} 25.18^{\prime \prime} \mathrm{N}$ and longitude $5^{0} 14^{\prime} 44.6022^{\prime \prime}$. The study area (Gudu Town) is located $15 \mathrm{~km}$ away from Sokoto town, and is as shown with an arrow indicating in Plate 1 bellow.

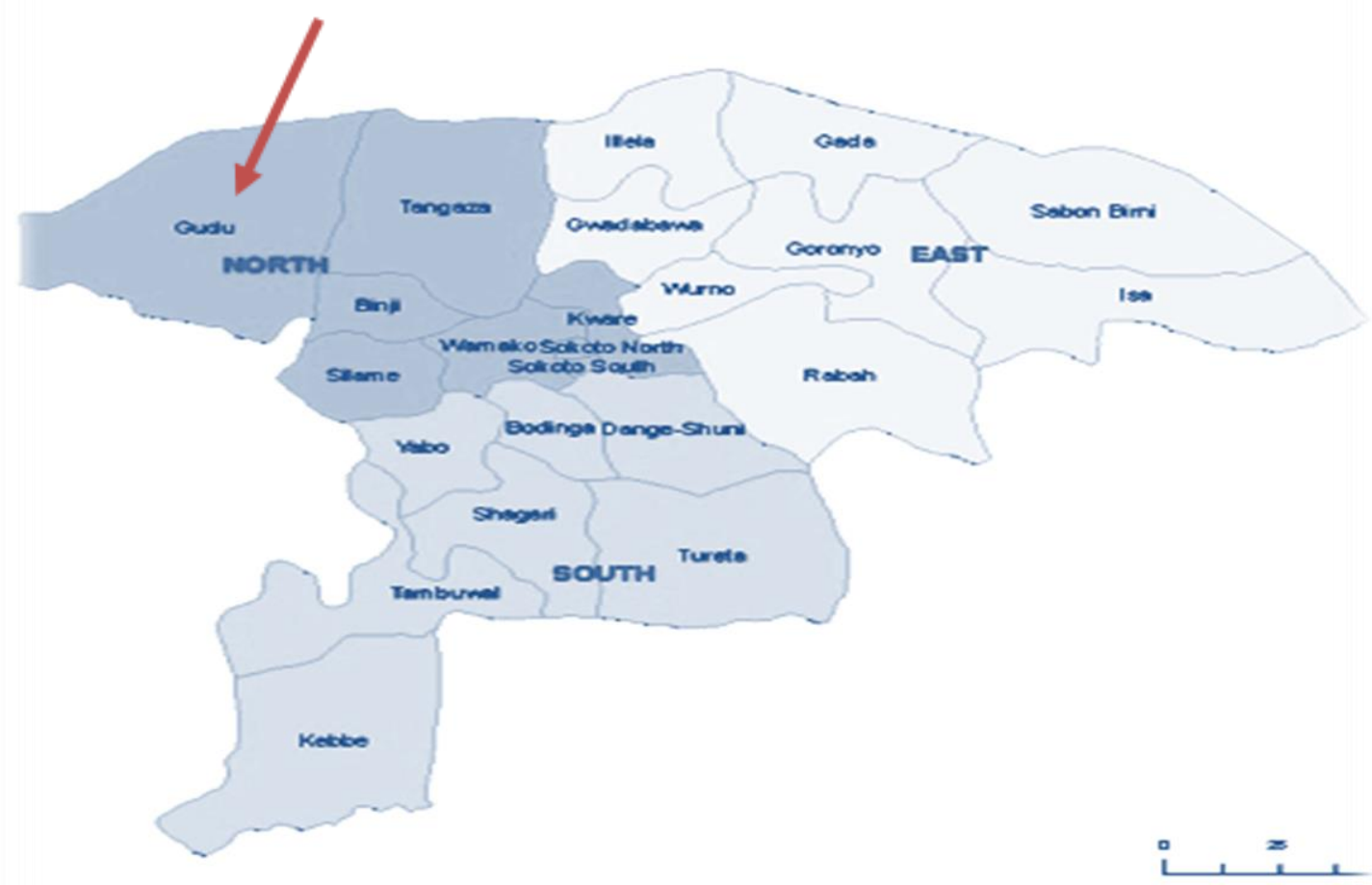

Plate1: Map of Sokoto State showing the Study Area

Oworoshoki area, Kosofe local government: It falls on latitude $6^{0} 27^{1} 10.8^{\prime \prime} \mathrm{N}$ and longitude $3^{0} 23^{1} 44.99^{\prime \prime} \mathrm{E}, 12 \mathrm{~km}$ from Lagos. The study area is as shown with an arrow indicating bellow in plate2.

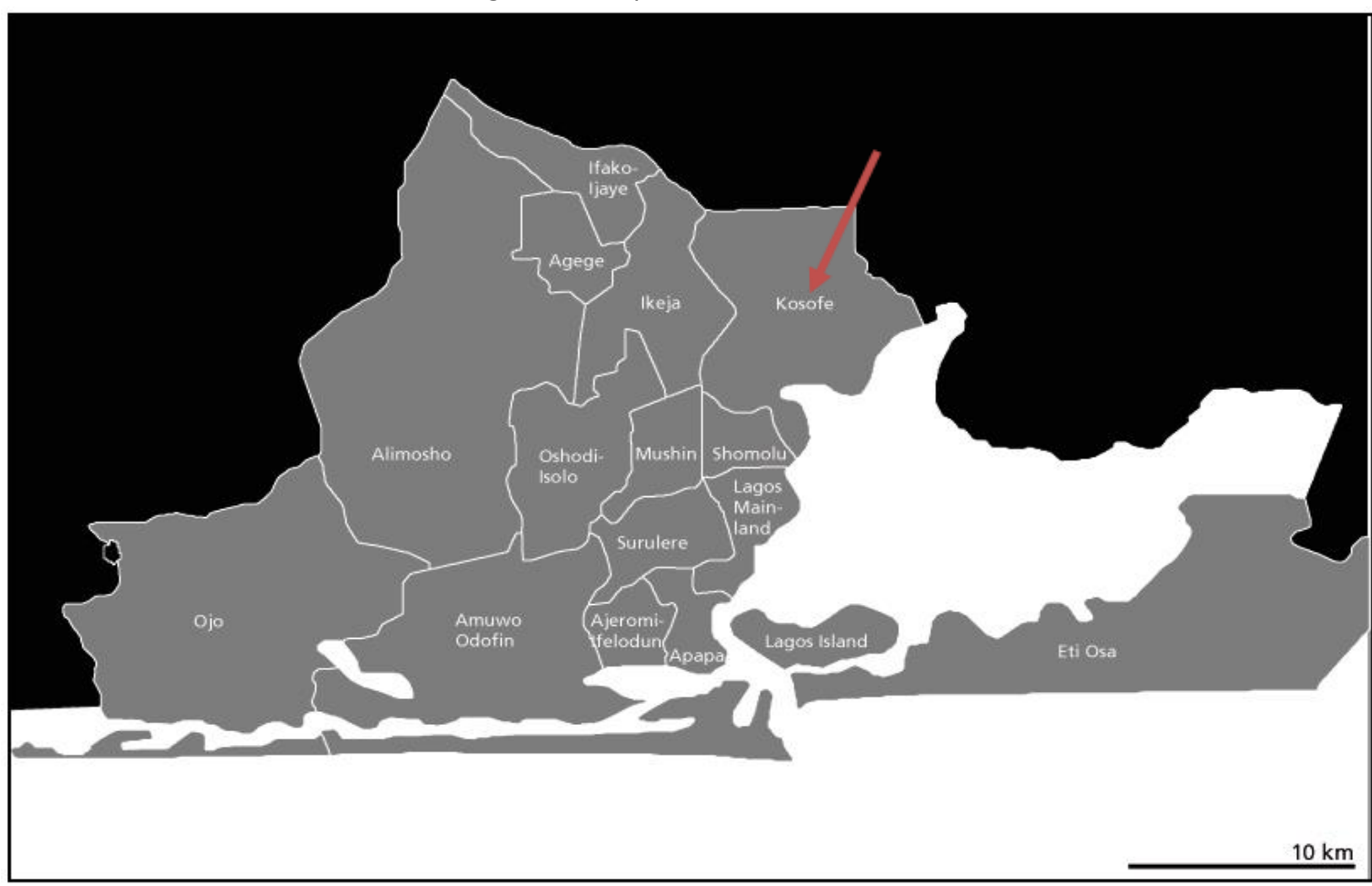

Plate2: Map of Lagos State showing the Study Area 


\section{Comparative Study of Soil Index Properties of Gudu Sokoto State and Oworoshoki Area Lagos State, Nigeria}

\section{RESULT}

This section compares the results obtained from the experiments and analysis conducted on Gudu and Oworoshoki. The result for the natural moisture content, specific gravity, sieve analysis, atterberg (liquid limit and plastic limit)) limit, unit weight and hydrometer test were presented in graphical format while characterization of the soil samples in tabular format.

\section{Natural Moisture Content}

Figure 1 below represent the natural moisture content of Gudu and Oworoshoki.

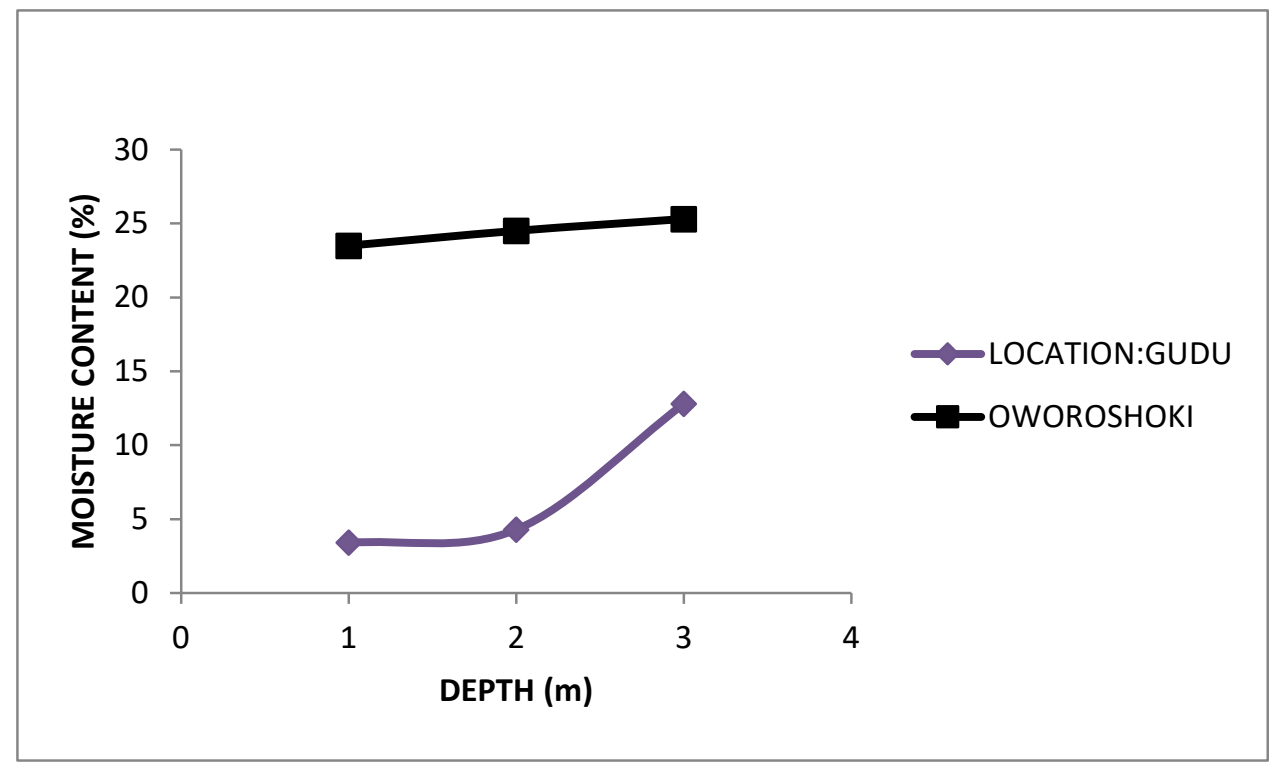

Figure 1 Gudu and Oworoshoki moisture content

\section{Specific Gravity}

The Specific gravity of Gudu and Oworoshoki soil samples are represented in Figure 2 below.

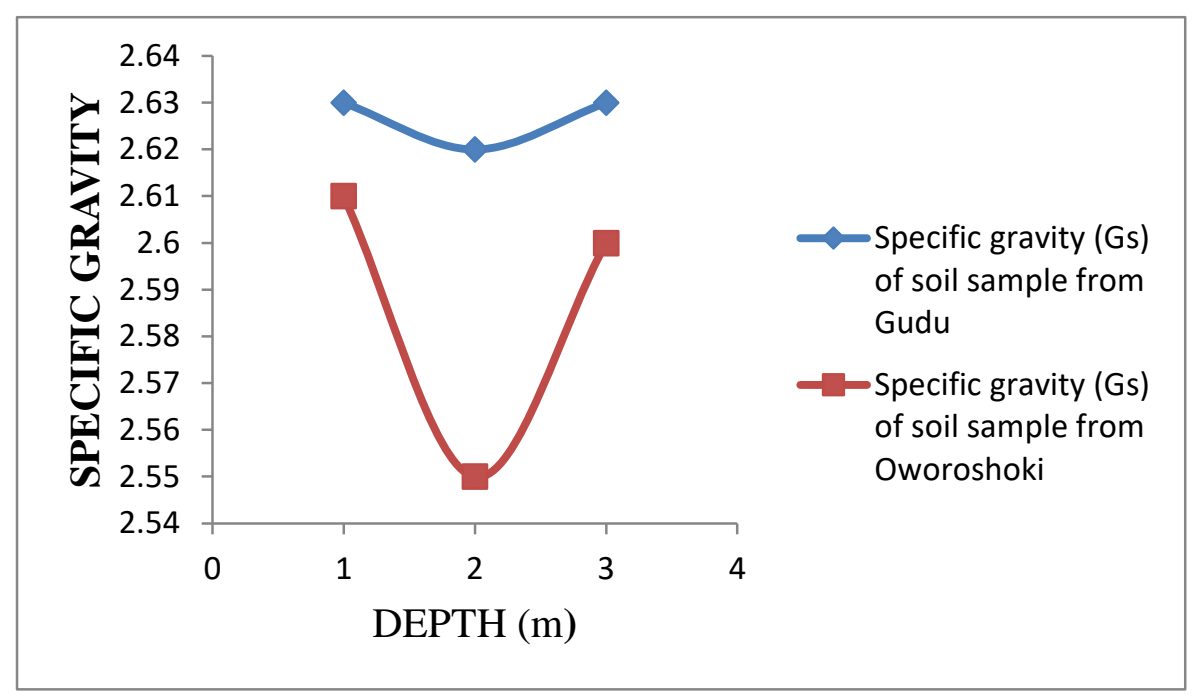

Figure 2. Specific gravity for gudu and oworoshoki

\section{Sieve Analysis}

The Sieve analysis result of soil samples collected from Gudu is as shown in Figure3 below. 


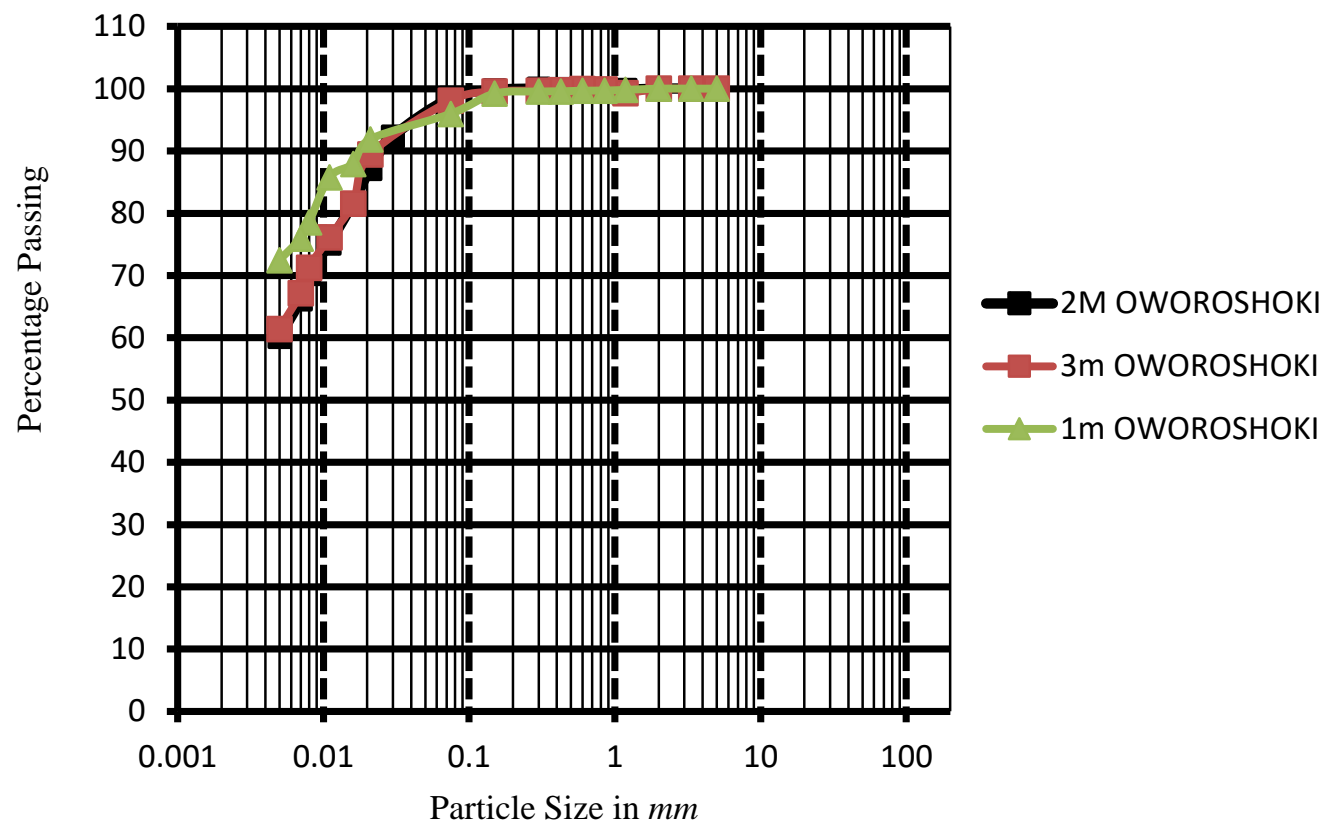

Figure 3 Sieve analyses of Gudu percentage passing against sieve size ( $\mathrm{mm})$

The Sieve analysis result of soil samples collected from Oworoshoki is as shown in Figure 4 below.

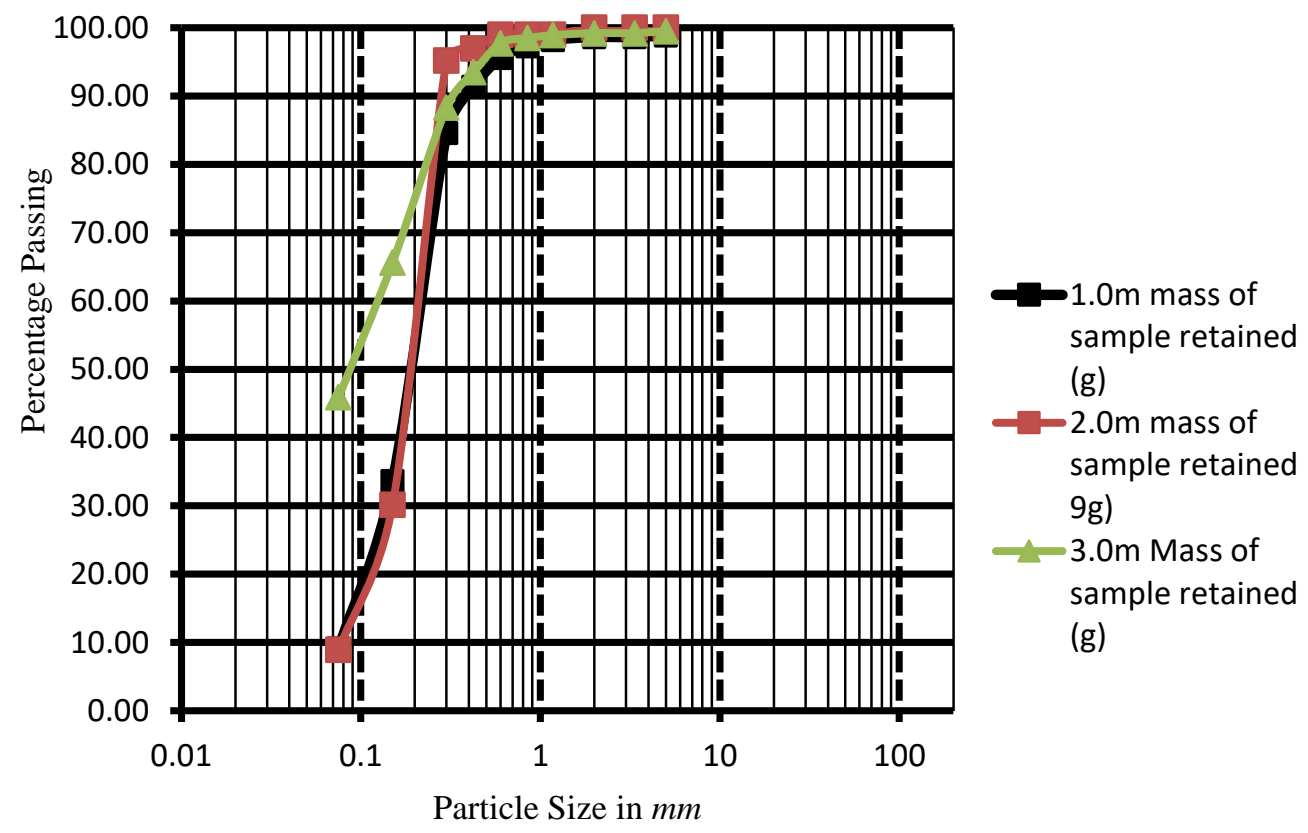

Figure 4 Sieve analysis graph for Oworoshoki

Atterberg Limit

Liquid limit graph of Gudu soil samples for $1 \mathrm{~m}, 2 \mathrm{~m}$ and $3 \mathrm{~m}$ are presented below in Figure 5,6 and 7 . 
Comparative Study of Soil Index Properties of Gudu Sokoto State and Oworoshoki Area Lagos State, Nigeria

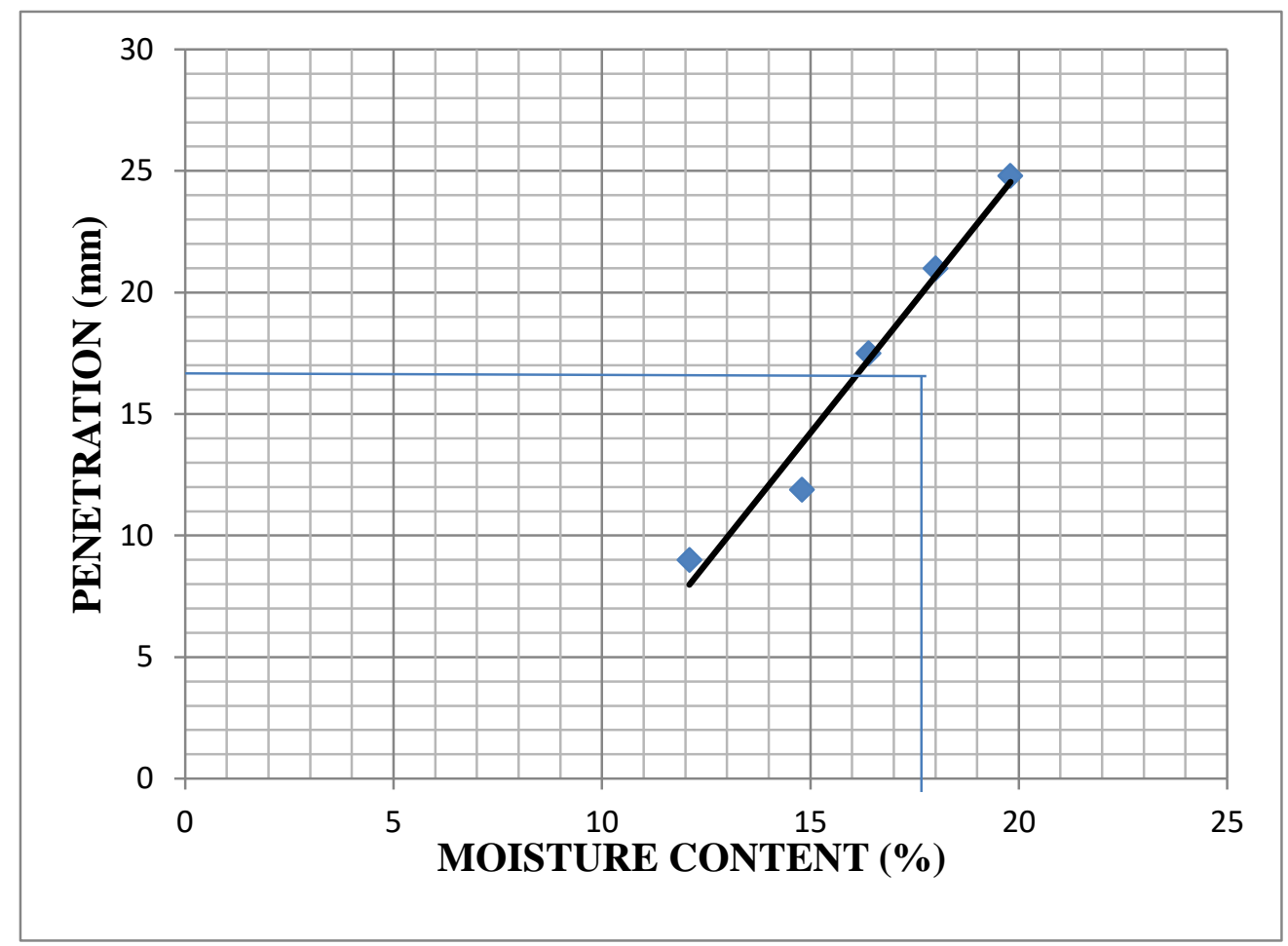

Figure 5 liquid limit for gudu at $1 \mathrm{~m}$ depth

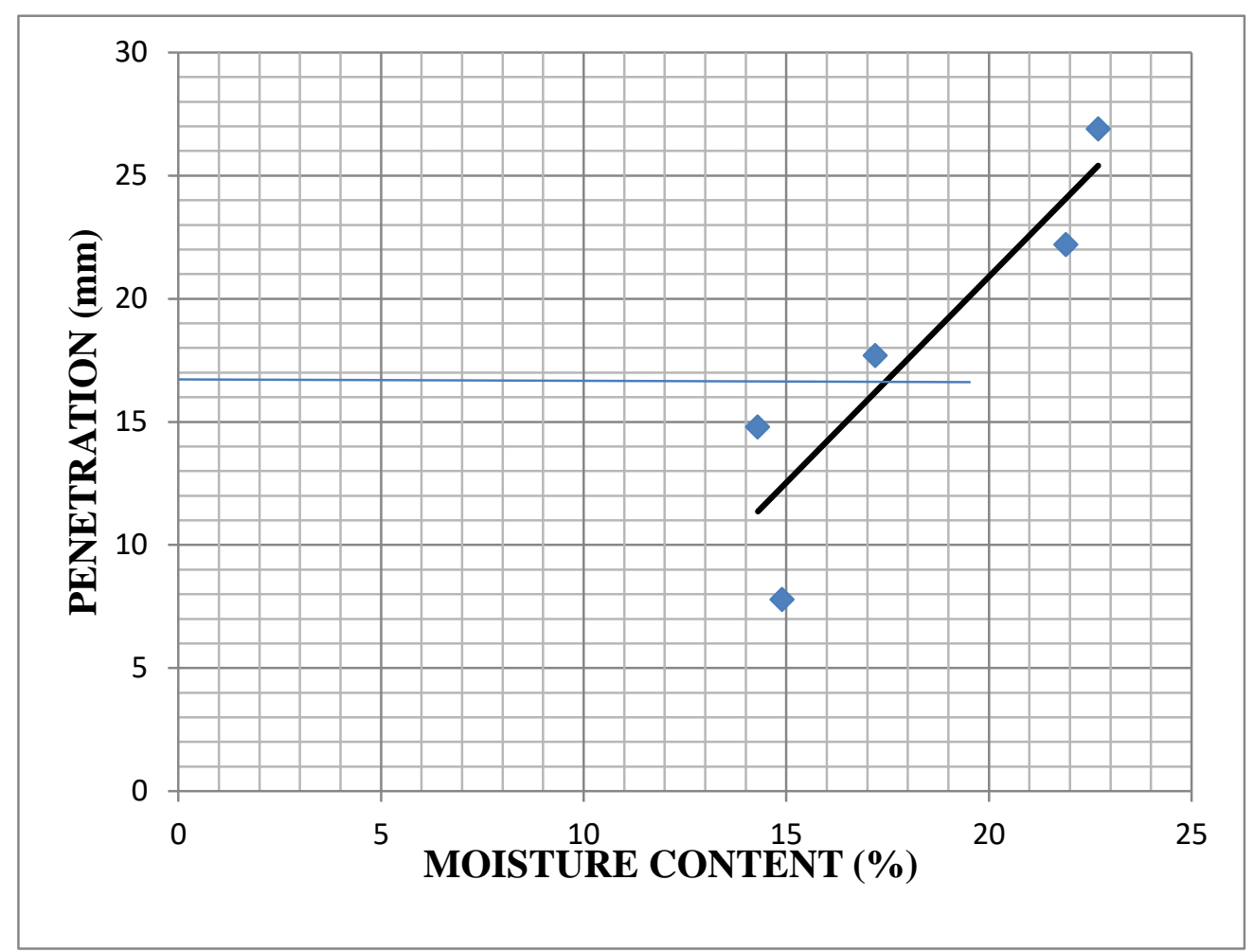

Figure 6 liquid limit for Gudu at 2m depth 
Comparative Study of Soil Index Properties of Gudu Sokoto State and Oworoshoki Area Lagos State, Nigeria

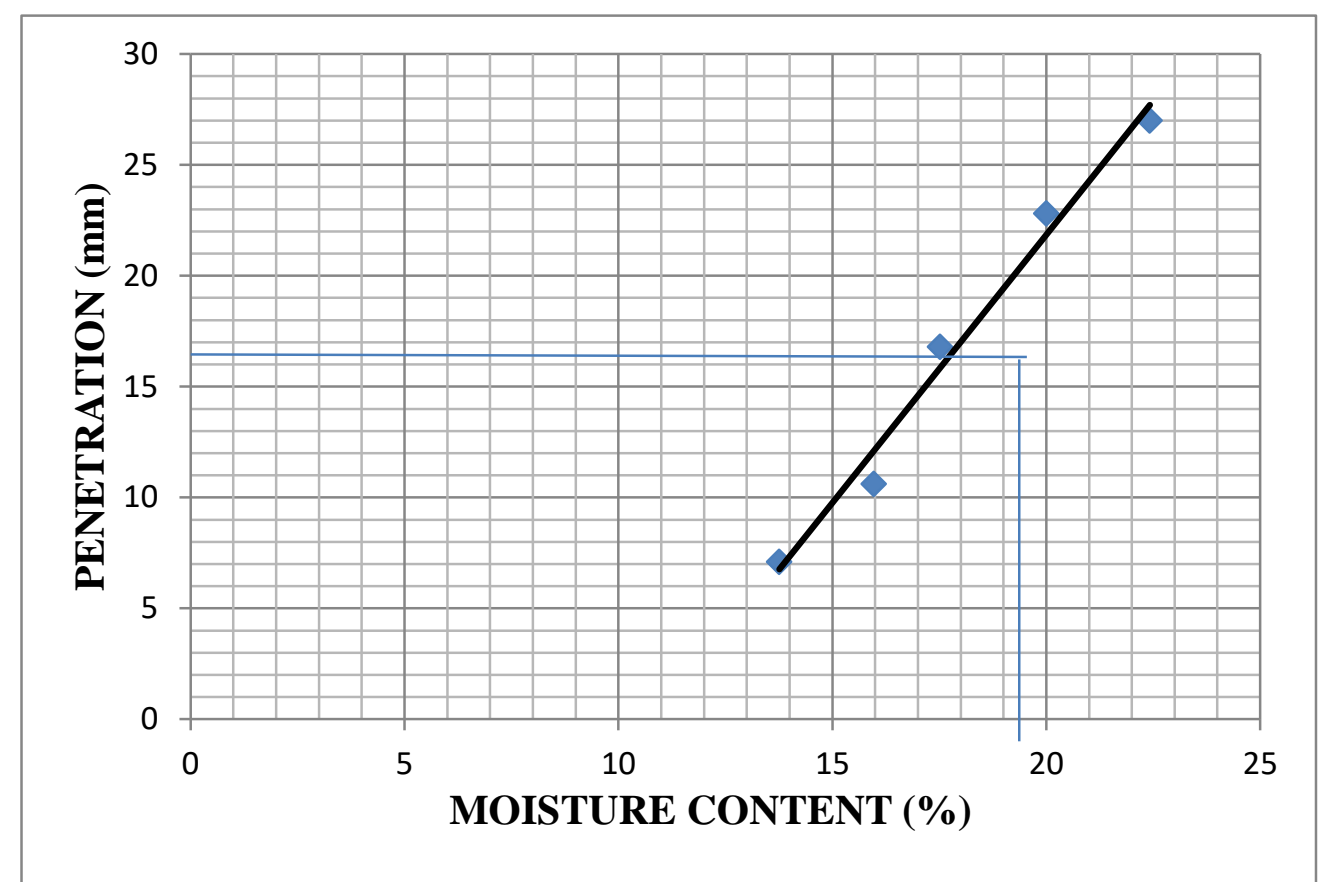

Figure 7 liquid limit for Gudu at 3m depth

\section{Unit Weight}

The graph of unit weight of Gudu and Oworoshoki are presented below in Figure 8 below.

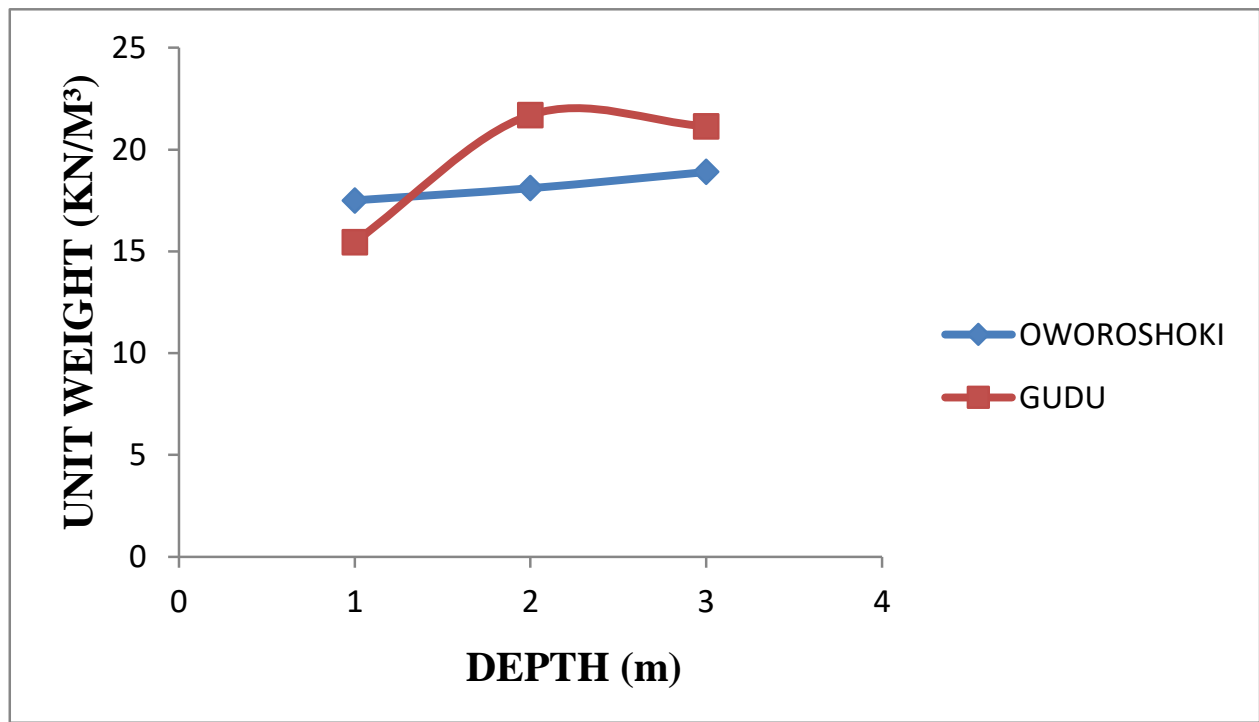

Figure 8 Unit weight graph for Gudu and Oworoshoki

Characterization of Gudu and Oworoshoki soil samples at $1 \mathrm{~m}, 2 \mathrm{~m}$ and $3 \mathrm{~m}$ depth is as shown in Table 1 and 2 below. Table1 Characterization of Gudu soil samples at $1 \mathrm{~m}, 2 \mathrm{~m}$ and $3 \mathrm{~m}$ depth.

\begin{tabular}{|l|l|l|l|}
\hline Characteristics & $1.0 \mathrm{~m}$ & $2.0 \mathrm{~m}$ & $3.0 \mathrm{~m}$ \\
\hline Natural moisture content (\%) & 3.4 & 4.3 & 12.8 \\
Specific Gravity & 2.63 & 2.62 & 2.62 \\
Unit Weight (KN/m3) & 15.45 & 21.70 & 20.15 \\
\%Passing B.S sieve 200 (0.075mm) & 9.10 & 8.97 & 45.90 \\
Liquid Limit (\%) & 19.50 & 17.40 & 19.20 \\
Plastic Limit (\%) & - & - & 12.13 \\
Plastic index (\%) & - & - & 7.07 \\
AASHTO Classification System & & A-3 & \\
& A-3 & A-4 \\
\hline
\end{tabular}




\section{Comparative Study of Soil Index Properties of Gudu Sokoto State and Oworoshoki Area Lagos State, Nigeria}

Table 2 Characterization of Oworoshoki soil samples at $1 \mathrm{~m}, 2 \mathrm{~m}$ and $3 \mathrm{~m}$ depth.

\begin{tabular}{|l|l|l|l|}
\hline \multicolumn{3}{|l|}{ Description } & $3.0 \mathrm{~m}$ \\
\hline Characteristics & $1.0 \mathrm{~m}$ & $2.0 \mathrm{~m}$ & 25.3 \\
\hline Natural Moisture content (\%) & 23.5 & 24.5 & 2.60 \\
\hline Specific Gravity & 2.61 & 2.55 & 18.9 \\
\hline Unit Weight (KN/m $\left.{ }^{3}\right)$ & 17.5 & 18.1 & 98.10 \\
\hline \% passing sieve 200(0.075mm) & 95.97 & 97.97 & 29.10 \\
\hline Liquid Limit \% & 28.68 & 26.64 & - \\
\hline Plastic Limit \% & - & - & - \\
\hline Plastic Index \% & - & - & $\mathrm{A}-3$ \\
\hline AASHTO Classification System & $\mathrm{A}-3$ & $\mathrm{~A}-3$ & \\
\hline
\end{tabular}

\section{DISCUSSION OF RESULTS}

This section compares the revealed information of soil samples collected from different geographical location at $1.0 \mathrm{~m}, 2.0 \mathrm{~m}$ and $3.0 \mathrm{~m}$ via laboratory analysis results.

\section{Natural Moisture Content}

From Figure 1 above, the values of the natural moisture content for Gudu are given as 3.4\%, $4.3 \%$ and $12.8 \%$, for olworoshoki are given as $23.5 \%, 24.5 \%$ and $25.3 \%$.It can be interpreted that the soil sample from Gudu has low retention capacity of water compared to Oworosghiki, the natural moisture content of Gudu is high at 3.0 depth, while Oworoshoki has the highest retention capacity of water of $25.3 \%$ at $3.0 \mathrm{~m}$ depth. This shows that Gudu soil sample is loosed compared to that of Oworoshoki. Oworoshoki shows that there is much silt in their soil sample.

\section{Specific gravity}

From Figure2 the average specific Gravity values of Gudu are given as 2.63, 2.62 and 2.63 for Oworoshoki as 2.61, 2.55 and 2.60. These values were obtained from treating each of the materials as a unit. The result shows that the specific gravity of sample from Gudu is 2.63 at $1.0 \mathrm{~m}$, fall at $2.0 \mathrm{~m}$ and rises at $3.0 \mathrm{~m}$, that of Oworoshoki is 2.61 at $1.0 \mathrm{~m}$ fall at $2.0 \mathrm{~m}$ and rises at $3.0 \mathrm{~m}$, Oworoshoki has the least specific Gravity of 2.55 .

\section{Particle Size Distribution}

From Figure3 and 4, Gudu soil sample, percentage passing through sieve size BS $200(0.0075 \mathrm{~mm})$ are $9.10 \%, 8.97 \%$ and $45.90 \%$ sample at depth $1.0 \mathrm{~m}$ and $2.0 \mathrm{~m}$ are non plastic materials they were classified as A-3 and sample at depth $3.0 \mathrm{~m}$ was classified as A-4 they have low plasticity with these it can be interpreted that soils under A-3 are fine wind-blow deserts and and soil in group A -3 are typically fine sands that may contain small amounts of non-plastic silt while soils in group A-4 which is $3.0 \mathrm{~m}$ is silty soils. Oworoshoki soil sample percentage passing through BS N200 (0.007) are 95.97\%, 97.97\%, 98.10\%. This shows that the soil sample contain much silt, the samples are non-plastic for all depths (1m, $2 \mathrm{~m}$ and $3 \mathrm{~m})$. Oworoshoki has the highest percentage passing though BS \#200 (0.075) with a value of $98.10 \%$ compare to Gudu.

\section{Alterberg Limits}

Form Figure5, 6 and7, the samples at $1 \mathrm{~m}, 2 \mathrm{~m}$ and $3 \mathrm{~m}$ have liquid limits values as $19.5 \%, 17.40 \%$ and $19.20 \%$ for Gudu, 28.68\%, $26.64 \%$ and $29.10 \%$, for Oworoshoki, Gudu has plastic limit at 3.0m only while Oworoshoki is non-plastic for the three depths which means $\mathrm{PI}=0$. According to ASHATO system, soil sample from Gudu at 3.0m depth has low plasticity.

\section{Unit Weight}

From Figure 8 the unit weight values of the sample for $1 \mathrm{~m}, 2 \mathrm{~m}$ and $3 \mathrm{~m}$ are $15.45 \mathrm{KN} / \mathrm{m}^{3}, 21.70 \mathrm{KN} / \mathrm{m}^{3}$ and $20.15 \mathrm{KN} / \mathrm{m}^{3} \mathrm{for} \mathrm{Gudu}$, it can be interpreted that sample from Gudu is high at $2.0 \mathrm{~m}$ and then fall at $3.0 \mathrm{~m}$. That of Oworoshoki is $17.5 \mathrm{KN} / \mathrm{m}^{3}, 18.1 \mathrm{kn} / \mathrm{m}^{3}$ and $18.9 \mathrm{KN} / \mathrm{m}^{3}$. This shows that, that of Oworoshoki rises simultaneously from $1.0 \mathrm{~m}$ to $3.0 \mathrm{~m}$. Gudu has the highest unit weight of $21.70 \mathrm{KN} / \mathrm{m}^{3}$ compare to Oworoshoki.

\section{Hydrometer}

Hydrometer test is only conducted for an appreciable quantity of soil sample that passed through BS 200 (0.075m). Base on this fact only Oworoshoki had the percentage passing through Bs $200(0.07 \mathrm{~mm})$ as $95.97 \%$ at $1.0 \mathrm{~m}$ depth, $97.97 \%$ at $2.0 \mathrm{~m}$ depth and $98.10 \%$ at $3.0 \mathrm{~m}$ depth. Gudu soil sample does not require hydrometer test. 


\section{Comparative Study of Soil Index Properties of Gudu Sokoto State and Oworoshoki Area Lagos State, Nigeria}

\section{CONCLUSION}

Base on the result obtained from the research carried out within the scope of this comparative study of the index properties of soils from Gudu and Oworoshoki. The following conclusion can be drawn:

Oworoshoki has the highest moisture content of $25.3 \%$ compare to Gudu with $12.8 \%$. While in terms of specific gravity Gudu has the highest with 2.63 compare to that of Oworoshoki with 2.61. Oworoshoki has the highest particle size distribution of $98.10 \%$ compare to that of Gudu with $45.90 \%$.Oworoshoki has the highest liquid limit of $29.10 \%$ while Gudu has $19.20 \%$.Gudu has the highest unit weight of $21.70 \mathrm{KN} / \mathrm{m}^{3}$ while Oworoshoki has $18.9 \mathrm{KN} / \mathrm{m}^{3}$. The sample collected at $1.0 \mathrm{~m}$ and $2.0 \mathrm{~m}$ are classified as A-3 according to AASHTO standard, they are good sub-grade materials and zero group index while sample collected at $3.0 \mathrm{~m}$ are classified as A - 4 according to AASHTO standard. Since Oworoshoki soil sample has the highest percentage Passing sieve $0.075 \mathrm{~mm}$ as $98.10 \%$. This shows that the soil contain high amount of silt. Soils from depth $1.0 \mathrm{~m}, 2.0 \mathrm{~m}$ and $3.0 \mathrm{~m}$ are classified as $\mathrm{A}-3$ according to AASHTO standard.

Hydrometer test is conducted mostly if a reasonable or appreciable percent of soil passes sieve $0.075 \mathrm{~mm}$. Base on this fact, Gudu soil sample does not require hydrometer.

\section{REFERENCES}

1) Akpokodje, E.G. (1989). Preliminary Studies of the Niger Delta sub soils. Engineering Geology, No. 26, Pp. 247 - 257.

2) Akpokodje, E.G. (2001).Introduction to Engineering Geology Properties of Earth Materials. Engineering Geology, Port Harcourt, Pp. $1-147$.

3) Arora, K.R. (2008).Soil Mechanics and Foundation Engineering (Geotechnical Engineering). $5^{\text {th }}$ edition, Pp. $427-428$. New Delhi, India. Standard Publishers Distributors.

4) Christodoulias, J. (2015). Engineering Properties and Shrinkage Limit of Swelling Soils in Greece. Journal of Earth Science and Climate Change, 6(5):279 doi: 104172/2157-7617.1000279.

5) Jain, V.K., Dixit, M. and Chitra, R. (2015).Correlation of plasticity index and compression index of soil.IJIET, 5(3): 263-270.

6) Laskar, A. and Pal, S.K. (2012).Geotechnical characteristics of two different soils and their mixture and relationships between parameters.EJGE, 17: 2821-2832.

7) Nwankwoala, H.O. and Warmate, T. (2014). Geotechnical assessment of foundation conditions of a site in Ubima, Ikwerre Local Government Area, Rivers State, Nigeria, IJERD, 9(8): 50-63.

8) Oghenero, A.E., Akpokodje, E.G. and Tse, A.C. (2014).Geotechnical properties of subsurface soils in Warri, Western Niger Delta, Nigeria.Journal of Earth Sciences and Geotechnical Engineering, 4(1): 89- 102.

9) Oke, S.A. and Amadi, A.N. (2008).An assessment of the geotechnical properties of the sub-soil of parts of Federal University of Technology, Minna, GidanKwano Campus, for foundation design and construction.J SciEducTechnol, 1 (2): $87-102$.

10) Oyediran, I. A. and Durojaiye, H. F. (2011). Variability in the Geotechnical properties of some residual clay soils from south western Nigeria. International Journal of Scientific \& Engineering Research Volume 2: 2229-5518.

11) Peni I.T. and Mustapha, A.M. (2021). Characterization and Classification of Geotechnical Index Properties of Shallow Soil Deposits at Oworoshoki Area, Kosofe Local Government, Lagos, Nigeria. International Journal of Multidisciplinary Research and Analysis, 04 (01): 415 - 424, DOI:10.47191/ijmra.

12) Peni, I.T. and Mustapha, A.M. (2019). Determination of Index Properties of Soil in Gudu Town, Sokoto, Nigeria. Science Association of Nigeria 2019, Conference in Collaboration with Usmanu Danfodiyo University, Sokoto. $14^{\text {th }}-18^{\text {th }}$ July, 2019.

13) Rorome, O. and Ekeocha, N.E. (2015).The Geotechnical Index Properties of soil in Warri, Delta State, Nigeria. Department of Geology, University of Port Harcourt, Port Harcourt, Nigeria. International Journal of Science Inventions Today, 4(1): 85-91.

14) Smith, M.J. (1994). Soil Mechanics. ${ }^{\text {th }}$ edition, Pp. 44 - 45. South Bank, England. Longman Singapore Publishers (PIc) Ltd.

15) Surendra, R.(2017).Role of Geotechnical Properties of Soil on Civil Engineering Structures. Journal of Scientific and Academic Publishing, 7(4):103 - 109, doi:10.5923/j.re.20170704.03.

16) Yoon, T.C., Yunus, N.Z.M., Marto, A., Hezmi, M.A., Jusoh, N.S and Ahmad, K. (2015). Comparison of soil index properties values for different pre - drying conditions on clayey soil. Journal of Technology: DOI: 10.11113/jt.v76.5429. 